\title{
RNF43 wt Allele
}

National Cancer Institute

\section{Source}

National Cancer Institute. RNF43 wt Allele. NCI Thesaurus. Code C107650.

Human RNF43 wild-type allele is located in the vicinity of $17 q 23.2$ and is approximately 65

$\mathrm{kb}$ in length. This allele, which encodes E3 ubiquitin-protein ligase RNF43 protein, plays a role in both signaling and protein ubiquitination. 